\title{
Value Orientation and Leadership Style among School Principals in Israel's Arab Education System
}

\author{
Jamal Abu-Hussain $^{1} \&$ Mohammad Essawi ${ }^{1}$ \\ ${ }^{1}$ Al-Qasemi Academic College of Education, Baqa El-Gharbieh, Israel \\ Correspondence: Mohammad Essawi, Al-Qasemi Academic College of Education, P.O. Box 124, Baqa El-Gharbieh \\ 30100, Israel. E-mail: moham.essawi1@gmail.com
}

Received: January 30, 2014

Accepted: April 9, 2014

Online Published: April 30, 2014

doi:10.5430/ijba.v5n3p49

URL: http://dx.doi.org/10.5430/ijba.v5n3p49

\begin{abstract}
The objective of the current study is to contribute to existing knowledge about the Arab education system in Israel. The study focuses on the school principals. They constitute the leadership of the Arab education system in the $21^{\text {st }}$ century to cope successfully with the many challenges. The Arab education system functions within a society still marked by clear signs of traditionalism and being in a state of transition to a more modern society. The system is undergoing many changes, ranging from the academization of school principals to accelerated feminization of the teaching profession. The study examines relationship between the principals' value orientation (pragmatic orientation versus moral orientation) and their leadership style (transactional leadership vs. transformational leadership) among school principals in Israel's Arab education system. The leadership styles of the principals were examined by a questionnaire along a continuum ranging from transactional leadership to transformational leadership. Data were collected from 100 school principals, constituting a randomly selected sample among 399 elementary school principals and 267 secondary school principals from the Arab education system in Israel (total of 666 principals). Sixty elementary school principals and 40 secondary school principals were randomly selected. The research results indicated that principals having a pragmatic value orientation tended to a transactional leadership style. In contrast, principals having a moral value orientation tended to a transformational leadership style.
\end{abstract}

Keywords: Arab education system, school principals, value orientation, leadership style

\section{Introduction}

Schools today function within a dynamic and complex environment. The success of a school derives from the ability its principal to adjust the school's structure and operations to the environment to respond quickly to contradictory requirements (Somech \& Reiter, 2005; Faraj, 2002; Abu-Hussain, 1998). School principals should be the central figures in education system. They should lead the education system in the $21^{\text {st }}$ century to cope with the challenges and provide functioning schools within the system undergoing extensive changes.

The Arab population of Israel is a minority marked by unique attributes. Researchers disagree on how to define Arab society in Israel. Is it a traditional and conservative society or is it a society undergoing a rapid transition from conservatism to modernization (Arar and Rigby, 2009). There are social and political changes in Arab society in Israel. Two parallel and perhaps even contradictory processes have resulted in conflicts on different levels of Arab society. On one level Arab society is marked by relations determined by a traditional clan mechanism. On another one, parallel level, Arab society has significant changes that can be caused by accelerated processes of modernization. The shift to new financial and occupational areas have gradually undermined traditional institutions. The cohesive extended family is weakening and is gradually being replaced by the nuclear family. The Arab educational system has not been immune to these processes (Abu-Asbah, 2007).

The Arab educational system in Israel is an integral part of the general educational system. For the most part it is run by Jewish administrators and defined as an educational system for Arabs rather than an Arab educational system. Local decisions made by low-level Arab functionaries are usually technical in nature, while the more fundamental decisions are not determined by Arab officials, despite the national and cultural distinctiveness of the Arab citizens of Israel. This situation has prevented Arabs in Israel from controlling the objectives of education or from shaping and directing the Arab educational system according to the collective interests of the Arab public. It has not enabled any meaningful intervention by Arab inspectors, principals, and educators in making any fundamental decisions for the system (Jabareen and Agbaria, 2010). 
The educational objectives of the Arab educational system are not clear, and the identity of the preferred graduate of this system has not been defined. Any possible attempts to define the objectives served to reinforce the ambiguity. Hence, the system operates without any vision. The principals and teachers have not objectives they should attain and don't know what types of graduates they should prepare (Reichel, 2008).

Recently the Ministry of Education of Israel has launched a process of decentralization by placing authority for teacher evaluation in the hands of school principals. This new approach has raised the issue of whether Arab school principals can carry out a professional and objective evaluation within a very complex reality. On the one hand, the principals are supposed to promote an organizational culture marked by standards and transparency. On the other hand, they are not allowed to make fundamental decisions regarding the schools they are charged with administering. The schools operate within the traditional and family-oriented social and cultural environment having a low level of transparency (Abu-Hussain and Gonen, 2013; Arar, 2010).

An individual's system of values characterizing personal value orientation is defined as a learned set of principles and rules that help the individual to choose among alternatives, resolve contradictions, and make decisions (Rokeach, 1973). Rokeach notes that values are a matter of perceptions that transcend any specific situation. An individual who espouses a particular value has complete confidence that a certain form of behavior is preferable to other forms of behavior from the personal, organizational, and social perspective. In line with Rokeach's definition, Sikula (1971) claims a value system of an individual determines his priorities, his world view, and the way in which he chooses his information and his behavior.

Human beings differ from one another with respect to the importance they attribute to various values. These diversified attitudes constitute an individual's hierarchy of values that reflect his personality and direct his perceptions, his evaluations, and his behavioral choices (Schwartz, 1996). Studies have found agreement on the group level with respect to the hierarchy of various values in different cultures, and have also revealed individual differences regarding value priorities (Knafo \& Schwartz, 2003; Schwartz \& Bardi, 2001).

Studies that examined the relationship between values and behavior found that values have an impact upon behavior in situations in which individuals are aware of their values (McClelland, 1997). Research has shown that values affect hypothetical behavior (Feather, 1995; Sagiv and Schwartz, 1995) as well as the choice of realistic behaviors (Schwartz, 1996).

Individual value orientation can be categorized as pragmatic value orientation and moral value orientation (Rokeach, 1973). Pragmatic value orientation is characterized by pragmatic values, such as achievement, obedience, ambitiousness, aggression, competition and the like. Moral value orientation is characterized by moral values such as tolerance in relations with others and interpersonal relations, equality, friendship, self and family security (Rokeach, 1973; Gaziel, 1982). This distinction between a pragmatic value orientation and moral value orientation has been found valid among business directors (England, 1975) and among school principals (Gaziel, 1982).

The needs of the organization and the needs of the individual affect leadership style. For some principals, the tendency to meet the needs of the organization dominates, while for others the needs of their subordinates are of prime importance. The current literature on leadership focuses on two directions of influence existing between leaders and those they lead. According to first direction a leader should generate a sense of cost-benefit among his subordinates. This direction is referred to transactional leadership (Avolio \& Bass, 2001). According to second direction of influence a leader should "generates emotions" by increasing the awareness of those they lead regarding what is important and correct and providing significance to what they do. This direction is referred to transformational leadership (Bass, 1999). Transformational leadership is directed towards creating a shared interest of leaders with those they lead. Furthermore, the interests of the organization and of its members must be adapted to each other (Gunter, 2001).

The results of a recent meta-analytic review of 25 years of research in the field of leadership indicate that transformational leadership correlates positively with the individual performance of those being led, with respect to several criteria. The results also revealed a positive relation between transformational leadership and the performance of the leadership staff and the organization (Wang et al., 2011). Transformational leadership was also found to be more closely tied to leader effectiveness and worker satisfaction than was transactional leadership (Deluga, 1988). Other researchers have examined the effect of transformational leadership style on organizational effectiveness and innovation and found that transformational leadership style has a more positive impact on organizational performance than does transactional leadership (Lowe et al., 1996).

This study examines relationship between the principals' value orientation (pragmatic orientation versus moral orientation) and their leadership style (transactional leadership vs. transformational leadership) among school principals in Israel's Arab education system. 


\section{Literature Review}

Numerous researchers have noted that a successful principal is an outstanding educational leader in two areas: providing support for teachers and effectively implementing organizational processes. Such a principal provides intellectual support for the teachers, offers them professional models and generates a sense of motivation among them toward improving their work. From an organizational perspective, a successful educational leader guides the organization, develops its common objectives, oversees and directs organizational performance, encourages effective communication and creates an empowering school culture in which teaching and learning are more intensive (Southworth, 2004; Leithwood, et al. 2006).

Because the principal is the leader of the school team, his leadership style is of prime importance. Leadership style affects various spheres: school climate, teacher satisfaction and teacher conduct in class, students' response to school requirements and more. The principal's leadership style has an impact on student achievements (Fullan, 2001), on the school's ability to cope with changes in the environment and on the level of effectiveness at the school (Sergiovanni, 1990; Nir \& Bogler, 2003). An open organizational climate yields good results with respect to teacher conduct. It improves teachers' organizational behavior, increases their dedication and raises the level of their teaching (Sergiovanni, 1990).

Miller \& Miller (2001) compare transactional leadership to transformational leadership as follows: "Transactional leadership is leadership in which relationships with teachers are based upon an exchange for some valued resource. To the teacher, interaction between administrators and teachers is usually episodic, short-lived and limited to the exchange transaction. Transformational leadership is more potent and complex and occurs when one or more teachers engage with others in such a way that administrators and teachers raise one another to higher levels of commitment and dedication, motivation and morality. Through the transforming process, the motives of the leader and follower merge" (Miller \& Miller, 2001, 182). Transformational leadership focuses on the process through which leaders can influence achievements at school and not only focus on results. These two terms appear in diverse studies and under alternative names (Bass, 1999; Eagly and Johnson, 1992; Popper, 1994).

The principals can be characterized as having a transactional or a transformational leadership style. The leadership style is likely to affect the way a principal conducts himself at the school. Transformational leadership has been shown to suit a complex and dynamic work environment which engenders diverse intellectual challenges to the principals and the educational staff (Leithwood, 1992). Studies have shown that transformational leader can cope with educational challenges in a changing environment and contributes to a school's ability to introduce innovations. The impact of such leaders can be seen in the areas of planning and organization as well as in the school's vision and culture (Cheng, 1997; Leithwood, 1992; Davies, 2007).

In today's stormy environment marked by ongoing change, leaders find themselves filling pivotal roles. Small and large organizations seek transformational leaders who can make the organizations competitive in rapidly changing world. Schools today face this same environment changes. Su-Tuan (2011) found that the transformational leadership style is appropriate to academic institutions. Educational leaders should not lead the organization based upon principles of give and take but rather based on the leader's personality and characteristics and on his ability to generate change and serve as a good example for those he leads (Su-Tuan, 2011).

A number of studies have corroborated the positive effects of transformational leadership on other variables at the school. Eyal and Roth (2011) found that transformational leadership has a positive influence on teachers' motivation and well-being and stimulates "autonomous motivation" in teachers. In addition, transformational leadership correlates negatively with teacher burn out, as opposed to transactional leadership, which elicits "controlled motivation" among teachers and correlates positively with teacher burn out (Eyal \& Roth, 2011). Hence, transformational leadership can be more effective than transactional leadership in organizing schools' activity required in the $21^{\text {st }}$ century.

The above findings lead to the conclusion that school leaders have the power to make a significant impact on processes and results through influence on behavior and performance of their subordinates. The studies surveyed above show that transformational leadership has a more positive impact than transactional leadership on behavior and performance. Thus, to be an educational leader a school principal must not only be engaged in administration but must also be actively and tangibly involved in developing the educational system and in overseeing its performance. Such a leader is expected to provide educational and pedagogic leadership at the school in order to improve both teacher performance and student learning.

Research and experience indicate that the job of school principals today is more complex, responsible and demanding than in the past. Over time their areas of responsibility have expanded and their work load has increased. 
The background of the varied activities and tremendous energy characterizing the work of school principals constitute the cultural values that allow to build their vision and that feed their passion at work. The values serve as their compass in going forward and grant meaning to their everyday activities (Southworth, 2009). A principal's set of values can influence the school's objectives, the processes that take place within the school and the directions in which it operates.

A study by Day, Harris \& Hadfield (2001) examined twelve schools in England and in Wales. It demonstrates the values that many school leaders have adopted. The study focused on principals who had been determined as effective leaders both their colleagues and according to the criteria of the Office for Standards in Education, Children's Services and Skills (Ofsted). The researchers interviewed teachers, parents, students and members of the schools' boards of directors, as well as the principals themselves. They noted that good leaders operate according to clear personal and educational perspectives and pass these on. These perspectives reflect their ethical convictions with respect to the school.

Numerous studies have found a relationship between the value orientation of leaders in business organizations and their leadership style. A study examining business organization in Jordan found that the leaders' value orientation is correlated significantly to their behavior on the job and their decision-making styles (Hayajneh, 1990). A study that examined 100 elementary school principals in Canada found that the principals' values in doing their job were important in their decision making and affected their everyday behavior (Armstrong and Trueblood, 1985). The results of a study examining four schools in different districts in Canada indicated that the principals' values affected their behavior and their decision-making processes (Moorhead \& Nediger, 1991). The four principals showed a preference for ethical values, and their conduct was marked by transformational behavior.

The relation between values and leadership style has been examined by two studies in Israel. In the first study, Gaziel (1982) examined a random sample of 80 undergraduate students studying educational management at Ben Gurion University, Bar-Ilan University, and Tel-Aviv University. The research participants completed a questionnaire on leadership style that had been developed by the researcher, as well as the completing the Rokeach Value Survey (1973). Gaziel found a correlation between students' values and their preferred leadership style. Those with a pragmatic value orientation tended to prefer a transactional leadership style, while those with a moral value orientation showed a preference for transformational leadership.

The second study was conducted among principals in the Arab school system in Israel (Abu-Hussain, 1998). This study showed that teachers perceived principals with a pragmatic value orientation as rewarding improved performance while penalizing inappropriate behavior, focusing on short-term assignments and seeking the shortest and most economical way to accomplish a task. That is, these principals exhibited a transactional leadership style. In contrast, principals with a moral value orientation were seen by the teachers as setting a personal example, eliciting the maximum from each teacher, relating to all those under them as basically good, nurturing teachers and encouraging them to be creative and to introduce changes to the system. The study also found a large distribution in the teachers' responses, indicating variance in the teachers' perceptions of the principals' leadership styles.

The above literature review points to a relationship between the values held by leaders and their behavior in the various spheres in which they operate. It emphasizes the importance of recognizing and understanding the factors impacting the leadership style of school principals. We can reasonably assume the finding that the leadership style of school principals is caused by influence of the values on an individual's behavior. We can reasonably assume that this relationship between values and leadership style also holds true among principals in the Arab educational system in Israel.

\section{Methods}

\subsection{Research Question}

Is there a relation between value orientation and leadership style among school principals in the Arab school system in Israel? What is the nature of this relation?

\subsection{Research Hypotheses}

- A positive relation will be found between a pragmatic value orientation and a transactional leadership style among school principals.

- A positive relation will be found between a moral value orientation and a transformational leadership style among school principals. 


\subsection{Research Variables}

\subsubsection{Dependent Variable}

Leadership style refers to a leader's on-the-job behavior on a continuum ranging from transformational leadership to transactional leadership. Transformational leadership finds expression in administrative behaviors that raise subordinates' level of awareness regarding the importance of their jobs and increases their level of enjoyment, maturity, and ambition. This type of leadership also takes into consideration the need for accomplishment and self-fulfillment as well as the welfare of others, the success of the organization and concern for the social environment (Bass, 1999). Transformational leadership brings about changes in the expectations and ambitions of those being led. In contrast, transactional leadership emerges in behaviors that focus on the immediate needs of subordinates. The leader tends to set clear goals, rewards performance and punishes inappropriate behavior (Popper, 1994).

\subsubsection{Independent Variable}

Value orientation refers to the set of principles and beliefs that influence the principal's thinking and behavior. This orientation is measured along a continuum ranging from pragmatic orientation to moral orientation. Pragmatic value orientation finds expression in values such as achievement, aggression, obedience, competition and success. In contrast, moral value orientation is marked by values such as tolerance, forgivingness, welfare, self-respect, individual and family security, relationship with others, equality and friendship (Rokeach, 1973).

To obtain the "pure" effect of value orientation (the independent variable) on leadership style (the dependent value), we chose to inspect the following background variables: type of school (elementary/secondary), school size (number of students), leadership courses, principal's level of education and seniority.

\subsection{Research Population and Sample}

The research population comprised a group of Arab elementary and secondary school principals in the Arab educational system in Israel. This system includes 399 elementary school principals and 267 secondary school principals, for a total of 666 school principals.

The sample was a stratified random sample, with 65 elementary school principals and 45 secondary school principals randomly chosen, for a total of 110 principals. The questionnaires of ten principals were disqualified for various reasons, mainly for failure to complete important and essential information.

\subsection{Research Tools}

Structured questionnaires served as the research tool used in this study, as follows:

1. Rokeach Value Survey (1973) questionnaire to examine principals' value orientation. This questionnaire includes 18 items representing terminal values, followed by 18 items representing instrumental values. The questionnaire's structure underwent factor analysis to examine the loading of the items into factors. The terminal values and the instrumental values underwent separate analyses. The results of the factor analysis testify to the validity of the structure of two contradictory value orientations: pragmatic and moral. Moreover, a high negative correlation coefficient $(\mathrm{r}=.70)$ was found between pragmatic orientation and moral orientation.

2. Questionnaire to examine leadership style among school principals. This questionnaire was designed to examine the leadership style of the school principals along a continuum ranging from transactional leadership to transformational leadership. The questionnaire used in the current study was taken from the Hebrew version widely used in research studies (Dvir, 1998). The questionnaire items were divided into two groups: transactional leadership and transformational leadership. The following items were grouped into the transactional leadership category: 1,4,11,12,16,17,20,22,24,27,29,32,35. The transformational leadership category contained the following items: $2,5,6,8,9,10,13,14,15,18,19,21,23,25,26,30,31,34,36$. Each scale was analyzed for homogeneity by means of Cronbach's alpha. The reliability values were high for both the transactional and the transformational leadership categories, .91 and .89 respectively. Items 3,7,28 and 33 were not grouped into either of the two scales. The reliability of the questionnaire, examined by Cronbach's alpha, was .90. The questionnaire also included background information about the principal and the school.

\subsection{Research Procedure}

The questionnaires were written in Arabic. The principals were asked to complete the questionnaires freely and accurately and to express their individual opinions in writing. All participants were told that the questionnaires would be anonymous and confidential and that the information was for research purposes only. 
All the questionnaires were administered by the researcher during the period October-December 2012. The questionnaires were administered individually by the researcher during forums for school principals run by the Ministry of Education as part of training on the topic of teacher evaluation. Upon completing the questionnaires, the participants submitted them directly to the researcher.

\subsection{Data Analysis}

The research hypotheses were examined by data analysis using SPSS. Stepwise regressions were used to examine the degree to which the variables of value orientation affected leadership style above and beyond the background variables. Because the regressions revealed no significant correlation between pragmatic value orientation and transactional leadership style, and in order to examine the relation between moral value orientation and leadership style among school principals, t-tests were conducted that compared the two measures of principals' perceptions: averages and standard deviations for principals with an moral value orientation and for those with a pragmatic value orientation. To determine the size of the effect of the independent variable on the dependent variable, the squared ETA was calculated (a parameter describing the percentage of explained variance, similar to $\mathrm{R}^{2}$ in regression analysis).

\section{Findings}

As stated above, the research hypotheses were as follows: School principals with a pragmatic value orientation will exhibit a tendency toward a transactional leadership style, while those with a moral value orientation will exhibit a tendency toward a transformational leadership style. The results with respect to this hypothesis are shown in Tables 1 and 2.

Stepwise regressions were conducted to examine the impact of the principals' background variables and set of values on their leadership style (Table 1). In each of the four stepwise regressions conducted, the first step included the following background variables: principal's educational level, whether or not he had taken a management course, seniority as principal, type of school (elementary/secondary), school size (number of students). In the first regression, the independent variable of moral value orientation was added as a second step. In the second regression, the independent variable of pragmatic value orientation was added. Two regressions were conducted, one for transactional leadership style and one for transformational leadership style. The independent variables were introduced into the regression in two stages. In the first stage, all the background variables of the principal and the school were introduced, while the variables of value orientation were introduced in the second stage. This method facilitated determining the degree to which the variables of value orientation affected leadership style over and above the effect of the background variables. The regression results are shown in Table 1.

Table 1. Regression coefficients ( $\beta$ ) of effect of background variables and value system on leadership style

\begin{tabular}{|c|c|c|c|c|}
\hline Leadership Style & $\begin{array}{l}\text { Transformational } \\
\beta\end{array}$ & $\mathbf{p}$ & $\begin{array}{l}\text { Transactional } \\
\beta\end{array}$ & $\mathbf{p}$ \\
\hline \multicolumn{5}{|l|}{ Block 1} \\
\hline School type & .30 & .001 & -.38 & .001 \\
\hline $\begin{array}{l}\text { Seniority as } \\
\text { principal }\end{array}$ & .26 & .06 & .26 & .03 \\
\hline School size & .05 & NS & -.05 & NS \\
\hline $\begin{array}{l}\text { Management } \\
\text { course }\end{array}$ & .01 & NS & .10 & NS \\
\hline $\begin{array}{l}\text { Principal's } \\
\text { education }\end{array}$ & -.05 & NS & -.001 & NS \\
\hline \multicolumn{5}{|l|}{ Block 2} \\
\hline moral values & .66 & .000 & -.26 & NS \\
\hline Pragmatic values & -.19 & NS & .43 & .02 \\
\hline
\end{tabular}

\section{Explained Variance}
A. Variance explained by the variables in Block 1 (background variables): $\mathrm{R}^{2}=.66, \mathrm{~F}(47,7)=11.38, \quad \mathrm{P}=.000, \quad \mathrm{R}^{2}=.68, \mathrm{~F}(47,7)=12.25, \mathrm{P}=.000$
B. Variance explained by the variables in Block 2 (independent variables): $\mathrm{R}^{2}=.156, \mathrm{~F}(47,7)=20.2, \mathrm{P}=.000 \quad \mathrm{R}^{2}=.04$ (not significant)
C. Total explained variance:
$\mathrm{R}^{2}=.67, \mathrm{~F}(46,10)=10.0, \mathrm{P}=.000, \mathrm{R}^{2}=.81, \mathrm{~F}(46,10)=20.9, \mathrm{P}=.000$ 
As can be seen in Table 1, among the background variables entered into Block 1 in order to obtain a "pure" effect of the independent variables (value orientation), only two were found to have a significant effect: type of school (elementary/secondary) and principal's seniority in school management.

With respect to the relation between the independent variable (value system) and the dependent value (leadership style), the results show that as the value orientation of principals becomes more moral, they tend to have a more transformational leadership style $\left(\mathrm{R}^{2}=.156, \mathrm{P}=.000\right)$, while principals with a pragmatic value orientation did not demonstrate a tendency toward a more transactional leadership style $\left(\mathrm{R}^{2}=.04\right.$, NS). Both regressions showed a high percentage of explained variance (.82). The variables of management course, education and school size were not significant in explaining principals' leadership style.

Because the regression did not find a significant relation between principals' pragmatic value orientation and transactional leadership style, an analysis of variance was carried out.

Table 2. Relation between principals' leadership style and value orientation

\begin{tabular}{lll}
\hline Value Orientation & Transformational Style & Transactional Style \\
\hline Average & & \\
Pragmatic $(\mathrm{n}=58)$ & & \\
M & 2.92 & 3.76 \\
SD & $(0.47)$ & $(0.75)$ \\
Moral $(\mathrm{n}=42)$ & 3.87 & 2.63 \\
M & $(0.24)$ & $(0.50)$ \\
SD & $-11.98^{* * *}$ & $8.02 * * *$ \\
t value & & \\
Distribution & & \\
Pragmatic (n=58) & 0.63 & 0.51 \\
M & $(0.25)$ & $(0.22)$ \\
SD $\quad(n=42)$ & 0.37 & 0.51 \\
Moral & $(0.22)$ & $(0.28)$ \\
M & $4.38^{* * *}$ & -0.15 \\
SD & & \\
$\mathrm{t}$ value & &
\end{tabular}

The findings in the above table show that at schools whose principals have a pragmatic value orientation the average score for transformational leadership was 2.92 (on a scale from 1 to 5), compared to an average attribution score of 3.76 at schools with principals characterized by a transactional leadership style. In contrast, at schools whose principals have a moral value orientation, the averages were 3.87 and 2.63 , respectively. The t-tests revealed significant correlations between pragmatic value orientation and transactional leadership style and between moral value orientation and transformational leadership style. To find the size of the effects of these two differences, squared ETA was calculated (a parameter describing the percentage of explained variance, similar to $\mathrm{R}^{2}$ in regression analysis), and the size of the effect was found to be .56 for transactional leadership and .73 for transformational leadership.

The regression analysis did not reveal a significant relation between principals with pragmatic value orientation and transactional leadership style. This result has a number of explanations, among them:

1. The background variables substantially explain the dependent variable (transactional leadership style) and do not leave much room for the effect of the independent variable (pragmatic value orientation).

2. Regression analyses with two independent values sharing similar factors have a statistical risk that most of the effect will be attributed to one of the independent values and not much effect will be left to be attributed to the other independent variable.

\section{Discussion and Conclusion}

The current study shows that the value orientation of school principals can affect their behavior on the job. It is reasonable to confirm that a principal with an ethical value orientation (who, as noted, tends toward a transformational leadership style) will be more successful in establishing a constructive school culture based on democratic values than a principal with a pragmatic value orientation (who, as noted, tends more toward a transactional leadership style), as noted by Su-Tuan (2011). This being the case, the success of a school is to a large 
extent dependent upon the degree of congruence between its organizational culture and the value orientation of its principal, as well as on the congruence between the school's structure and function and the environment in which it operates (as noted by Somech \& Reiter, 2005).

The results of the current study reveal a relation between the value orientation of school principals and their leadership style. The two research hypotheses were corroborated. In line with the first hypothesis, a pragmatic value orientation among school principals was found to be related to a transactional leadership style. Examination of the second hypothesis revealed a strong correlation between moral value orientation and transformational leadership style $\left(\mathrm{R}^{2}=.156, \mathrm{P}=.000\right)$, a correlation that testifies to a strong relationship between them.

Hence, a principal with a moral set of values, who is more likely to conform with a transformational leadership style than a principal with a pragmatic value orientation, can, together with the teachers, build a constructive culture at the school allowing to cope successfully with a changing and competitive reality. In such a reality, leadership style is considered to have major significance in the success of organizations, at that human resources serve as the main factor in the success and prosperity of organizations. School principals should be made aware of their value orientation. This awareness is likely to enable principals to deviate from their value orientation in making decisions and in running the school.

In line with the findings of various studies (Abu-Hussain, 1998; Somech and Reiter, 2005; Eyal and Roth, 2011; Wang et al., 2011), can affirm that principals with an ethical value orientation (who, as noted, tend toward a transformational leadership style) make a greater contribution to school effectiveness than do principals with a pragmatic value orientation (who, as, noted, tend toward a transactional leadership style). Based upon this affirmation, the educational system can use the findings of this study in selecting school principals and planning appropriate training procedures directed towards of adoption of a transformational leadership style by current and future principals of schools in the Arab education system in Israel. Moreover, conducting research in the Arab educational system should examine specific connections between value orientation and leadership style.

\section{References}

Abu-Asbah, K. (2007). The Arab Education System in Israel: Dilemmas of a National Minority. Jerusalem: Florscheim Institute for Policy Research, Jerusalem [Hebrew].

Abu-Hussain, J. (1998). Value orientation and leadership styles of school principals in Israel's Arab sector. In: Studies in educational Administration and Organization, 22, 87-100 [Hebrew].

Abu-Hussain, J., \& Gonen, S. (2013). Education for responsibility and responsibility for education. Mofet Institute and Al-Qasemi College of Education, Tel-Aviv [Hebrew].

Abu-Saad, I. (2006). State-controlled education and identity formation among the Palestinian Arab minority in Israel. American Behavioral Scientist, 49(8), 1085-1100. http://dx.doi.org/10.1177/0002764205284720

Arar, K. (2010). Perception and use of teacher evaluation among elementary school principals in the Arab school system in Israel. Iyunin beminhal ubairgun hachinuch (Studies in educational administration and organization), 31, 325-349 [Hebrew].

Arar, K., \& Rigby, A. (2009). To participate or not to participate'-status and perception of physical education among Muslim Arab-Israeli secondary school pupils. Sport, Education and Society, 14(2), 183- 202. http://dx.doi.org/10.1080/13573320902809088

Armstrong, M., H., \& Trueblood, C. (1985). The Importance of Principals' Values and their Relationships to the Promotion of Professional teachers Growth. Eric Document Reproduction service (ED263668).

Avolio Bruce J. (Ed.), \& Bass Bernard M.(Ed). (2001). Developing Potential across a Full Range of Leadership TM: Cases on Transactional and Transformational Leadership. Psychology Press.

Bass, B.M. (1999). Two decades of research and development in transformational leadership. European journal of work and Organizational Psychology, 8, 9-32. http://dx.doi.org/10.1080/135943299398410

Cheng, Y. Ch. (1997). The Transformational Leadership for School Effectiveness and Development in the New Century. Paper read at International Symposium of Quality Training of Primary and Secondary Principals toward the 21st Century, January 20-24, at Nanjing, China.

Davies, B. (2007). Developing Sustainable Leadership. London: Paul Chapman Publishing.

Day, C., Harris, A., \& Hadfield, M. (2001). Challenging the Orthodoxy of Effective School Leadership. International Journal of Leadership in Education, 4(1), 39-56. http://dx.doi.org/10.1080/13603120117505 
Deluga, R. J. (1988, December). Relationship of Transformational and Transactional Leadership with Employee Influencing Strategies. Group Organization Management, $13(4), \quad 456-467$. http://dx.doi.org/10.1177/105960118801300404

Dvir, T. (1998). The impact of transformational leadership training on follower development and performance: a field experiment. Ph.D. Dissertation, Faculty of Management. Tel-Aviv University.

Eagly, A. H., \& Johnson, B. T. (1992). Gender and Leadership Style among School Principals: A Meta-Analysis. Educational Administration Quarterly, 28, 76-102. http://dx.doi.org/10.1177/0013161X92028001004

England, G. W. (1975). The Manager and His Values, An International Perspective. Cambridge, Mass: Ballinger.

Eyal, R., \& Roth, G. (2011). Principals' leadership and teachers' motivation Self-determination theory analysis. Journal of Educational Administration, 49(3), 256-275. http://dx.doi.org/10.1108/09578231111129055

Faraj, H. (2002). Self-efficacy of Arab teachers as the result of environmental and personal factors. Doctoral thesis, Faculty of Education, University of Haifa [Hebrew].

Feather. N. T. (1995). Values, valences\& choice: The influence of values on the perceived attractiveness and choice of alternatives. Journal of personality and Social psychology, 68, 1135-1151. http://dx.doi.org/10.1037/0022-3514.68.6.1135

Fullan, M. (2001). Leading in a culture of change. San Francisco: Jossey-Bass.

Gaziel, H. (1982). Relationship between the values of students of educational administration and their perceptions of ideal management style. Iyunin beminhal ubairgun hachinuch (Studies in educational administration and organization), 10, 57-68 [Hebrew].

Gaziel, H. (1990). Contemporary Management Thought. Ramot Publications: Tel-Aviv University [Hebrew].

Gunter, H. (2001). Leaders and Leadership in Education. London: Paul Chapman.

Hayajneh, A. F. (1990). Personal value system of American and Jordanian Manager: A cross cultural study. Dissertation Abstract International, University of North Texas-1991, 2450A.

Jabareen, Y., \& Agbaria, A. (2010). Education on hold: Government policies and citizen initiatives to promote Arab education in Israel. Haifa: Dirasat [Hebrew].

Knafo, A., \& Schwartz, S. (2003). Passing on Family Values. Jerusalem: NCJW Research Institute for Innovation in Education [Hebrew].

Leithwood, K. (1992). The Move Toward Transformational Leadership. Educational Leadership, 49(5), 8-12.

Leithwood, K., Day, C., Sammons, P., Harris, A., \& Hopkins, D. (2006). Successful School Leadership: What it is and how it influences pupil learning. London: DfES.

Lowe, K., Kroeck, G., \& Sivasubramaniam, N. (1996). Effectiveness correlates of transformational and transactional leadership: A meta-analytic review of the MLQ literature, Leadership Quarterly, 7(3), 385-425. http://dx.doi.org/10.1016/S1048-9843(96)90027-2

McClelland, D.C. (1997). Human Motivations. Cambridge university press.

Miller, T. W., \& Miller, J. M. (2001). Educational leadership in the new millennium: a vision for 2020. International Journal of Leadership in Education, 4(2), 181-189. http://dx.doi.org/10.1080/13603120120806

Moorhead, R., \& W. Nediger, (1991). The Impact of Values on a Principal's Daily Activities. Journal of Educational Administration, 29(2), 5-24. http://dx.doi.org/10.1108/09578239110003732

Nir, A., Bogler, R. (2003). Organizational vision in self-managing schools: Walking on thin ice. In A. Volanski and I. A. Friedman (Eds.), School-Based Management. An International Perspective. Jerusalem: Ministry of Education [Hebrew].

Popper, M. (1994). On Principals as Leaders. Ramot Publications: Tel Aviv University [Hebrew].

Reichel, N. (2008). The story of the Israeli educational system. Jerusalem: Magnes Press [Hebrew].

Rokeach, M. (1973). The Nature of Human Values. New York: Free Press.

Sagiv, L., \& Schwartz, S. H. (1995). Value priorities \& Readiness for out group social contact. Journal of personality and Social psychology, 69, 437-448. http://dx.doi.org/10.1037/0022-3514.69.3.437 
Schwartz, S. H. (1996). Value priorities \& Behavior: Applying a theory of integrated value orientation. In C. Seligman, J. M. Olson\& M. P. Zanna (Eds.), The Ontario symposium: Vol. 8. The psychology of values (pp. 1-24). Hillsdale, NJ: Lawrence Erlbaum.

Schwartz, S. H., \& Bardi, A. (2001). Value hierarchies across cultures: Taking a similarities perspective. Journal of cross cultural psychology, 32, 268-290. http://dx.doi.org/10.1177/0022022101032003002

Sergiovanni, T. J. (1990). Adding value to leadership gets extraordinary results. Educational leadership, 47, 23-27.

Sikula A. F. (1971). Values and Value orientation: Importance and Relationship to Managerial and Organizational Behavior. Journal of Psychology, 25, 227-286.

Somech, A., \& Reiter, S. (2005). Perception of role of leader in the Arab Sector - Impact of management style and organizational climate on school effectiveness. Doctoral thesis, Faculty of Education, University of Haifa [Hebrew].

Southworth, G. (2004). Primary School Leadership in Context: Leading small, medium and large sized schools. London: Routledge Falmer.

Southworth, G. (2009). Passionate work: towards a natural history of headship. In Davies \& Brighouse (Eds.). The Essentials of School Leadership ( $2^{\text {nd }}$ ed.). London, Sage.

Su-Tuan, L. (2011). Transformational Leadership: Leadership in Education. Educause.edu. According to the abstract, Created by Su-Tuan Lulee (WIDE) on March 13, 2011.

Wang, G., Oh, I.S., \& Courtright, S. (2011). Transformational Leadership and Performance across Criteria and Levels: A Meta-Analytic Review of 25 Years of Research. Group Organization Management, 36(2), 223-270. http://dx.doi.org/10.1177/1059601111401017 